\title{
Two cases of thrombohaemolytic thrombocytopenic purpura associated with changes in red cell morphology
}

\author{
P. MCCORMACK ${ }^{1}$, D. J. O'BRIEN, AND R. A. M. OLIVER \\ From the Group Laboratory and Mayday Hospital, Croydon, Surrey
}

SYNOPSIS Two adult cases of thrombohaemolytic thrombocytopenic purpura are described. Both showed striking morphological changes in the red cells with increased saline osmotic fragility, in o addition to thrombocytopenia and generalized hyaline thrombi affecting small blood vessels. ㅇ These changes support the hypothesis that this is a triple auto-immune disorder affecting red cells, platelets, and small blood vessels.

Since Moschcowitz (1925) published the first case under the title 'An acute febrile pleiochromic anaemia with hyaline thrombosis of terminal arterioles and capillaries - an undescribed disease', rather more than a hundred cases of a syndrome characterized by acute febrile haemolytic anaemia, thrombocytopenia, and transient neurological signs have been described. We publish here two further cases under the title 'Thrombohaemolytic thrombocytopenic purpura' proposed by Adelson, Heitzman, and Fennessey (1954), since we feel that they shed further light on the pathogenesis of the condition with particular reference to the anaemia.

\section{CASE REPORTS}

CASE 1 An analytical chemist, aged 24, had had no known exposure to toxic chemicals apart from the occasional use of small quantities of nitrobenzene. Eight days before admission to this hospital he developed nausea, fever, and slight jaundice. Immediately before admission he had a grand mal convulsion and became comatose. On examination he was febrile (temperature $103^{\circ} \mathrm{F}$.), pale, and jaundiced with a widespread purpuric rash. The spleen was not palpable. He was deeply unconscious with a spastic right hemiplegia, both plantar responses being extensor.

Laboratory investigations Haemoglobin was $41 \%$ (6.1g. per $100 \mathrm{ml}$ ); P.C.V. $18 \%$; M.C.H.C. $34 \%$; nucleated red cells 13 per 100 W.B.C.s; reticulocytes $26 \%$; W.B.C.s 29,000 per c.mm. (polymorphs $50 \%$, eosinophils $2 \%$, lymphocytes $45 \%$, monocytes $3 \%$ ); a film showed gross anisocytosis with spherocytosis; E. S. R. (Wester-

Received for publication 3 December 1962.

'Now at St. Mary's Hospital, London, W.2. gren) $30 \mathrm{~mm}$. in one hr.; platelets 85,000 per c.mm.; red cell osmotic fragility markedly increased (haemolysis $\mathscr{\odot}$ began at $0.7 \% \mathrm{Na} \mathrm{Cl}, 50 \%$ occurred at $0.47 \%$, and was $\omega$ complete at $0.25 \%$ ). The blood group was $\mathrm{O}$ Rh-positive to anti-D. A direct Coombs test was negative. The bleeding time (Duke's method) was over 15 minutes, and the clotting time (Wright's method) 3 minutes. Liver function tests showed a serum protein level of $7.0 \mathrm{~g}$. per $100 \mathrm{ml}$; $\frac{\mathrm{O}}{\mathrm{D}}$ electrophoresis was normal apart from diminished $\gamma \propto$ globulin; zinc sulphate turbidity 0.5 units; alkaline phos- $\overrightarrow{\overrightarrow{0}}$ phatase 9.0 units; bilirubin $3.5 \mathrm{mg}$. per $100 \mathrm{ml}$.; direct van 3 den Bergh reaction was negative. Spectroscopy of the $כ$ urine and serum was negative. The urine showed a trace of urobilinogen with a slight increase in protein $(185 \mathrm{mg}$. per $100 \mathrm{ml}$.) and occasional granular casts. Blood urea level was $25 \mathrm{mg}$. per $100 \mathrm{ml}$. Blood culture on several occasions $\dot{0}$ proved sterile. The cerebrospinal fluid was normal with a protein of $48 \mathrm{mg}$. per $100 \mathrm{ml}$. and no increase of cells.

He was treated with penicillin in high dosage and blood transfusions initially, followed by prednisolone $\mathbf{4 0} \mathrm{mg}$. a day. He remained febrile and unconscious, developed bilateral retinal haemorrhages and more extensive pur- $\frac{D}{2}$ pura, and died two weeks after the onset of symptoms.

CASE 2 A part-time nurse, aged 38, had not been exposed to toxic chemicals or drugs. She had a three $N$ weeks' history of tiredness, weakness, and spontaneous bruising of the legs, followed by bleeding from the gums, $\sigma$ which had been exacerbated by a dental extraction one week before admission. On examination she was found to $\stackrel{0}{=}$ be afebrile, pale, and slightly jaundiced with generalized $\mathscr{\Phi}$ bruises, but no petechiae. The spleen and lymph nodes ?+ were not palpable but the liver was very tender and $T_{T}$ enlarged 3 in. below the costal margin. There were no abnormal neurological signs, but within a few hours of $\stackrel{\mathbb{Q}}{\Omega}$ admission she became disorientated and was found to have $\mathbb{D}$ a left hemiplegia with a temperature of $102^{\circ} \mathrm{F}$. 
Laboratory investigations Haemoglobin was $41 \%$ (6.1 g. per $100 \mathrm{ml}$.). P.C.V. $16 \%$; M.C.H.C. $37 \%$; nucleated red cells 2 per 100 W.B.C.s; reticulocytes $21 \%$; E.S.R. (Westergren) $43 \mathrm{~mm}$. per $1 \mathrm{hr}$.; platelets 25,000 per c.mm.; W.B.C.s 28,500 per c.mm. (polymorphs $84 \%$, metamyelocytes $2 \%$, myelocytes $1 \%$, lymphocytes $10 \%$, monocytes $3 \%$ ). A film showed that the red cells were well haemoglobinized with marked anisocytosis and polychromasia ; there were also many spherocytes and schistocytes. Red cell osmotic fragility was markedly increased. (Haemolysis began at $0.7 \%, 50 \%$ occurred at $0.52 \%$, and it was complete at $\mathbf{0 . 3 2} \%$.) The blood group was $\mathbf{O} \mathbf{R h}$ negative to anti-D. A direct Coombs test was negative. Prothrombin time (Quick) was 20 seconds (control 13 seconds). A Hess test was negative. Liver function tests showed a serum protein level of $6.6 \mathrm{~g}$. per $100 \mathrm{ml}$; electrophoresis was normal; bilirubin $2.0 \mathrm{mg}$. per $100 \mathrm{ml}$.; direct van den Bergh reaction negative; alkaline phosphates 6 units; glutamic oxalacetic transaminase 35 pyruvic units; glutamic pyruvic transaminase 42 pyruvic units. Schumm's test for methaemalbumin was positive. Serum spectroscopy was negative. The urine showed an increase of urobilin and urobilinogen with no other abnormalities. The blood urea level was $59 \mathrm{mg}$. per $100 \mathrm{ml}$. Blood culture on two occasions proved sterile. Radiographs of the chest and abdomen showed no significant abnormality.

She was treated with vitamin $\mathrm{K}$ parenterally in view of the raised prothrombin time, and with prednisolone in a dose of $60 \mathrm{mg}$. per day after the diagnosis of thrombotic microangiopathy was made following the neurological episode. She remained pyrexial, developed widespread purpura, bilateral retinal haemorrhages, and died in coma three days after admission.

\section{NECROPSY FINDINGS}

Widespread petechiae were the only prominent feature of the post-mortem examinations macroscopically in both cases. They were particularly conspicuous in the brain, there being groups of petechiae in the cerebral and cerebellar cortex, basal ganglia, and pons. In case 1 there was a small subdural haematoma. Neither case was jaundiced at death. Both showed hyperplasia of dark red marrow in the femur, which extended one-third of the way down the shaft in both cases. A parenchymatous adenoma of the liver $(3.0 \mathrm{~cm}$. diam.) was present in case 2.

On microscopic examination dilated capillaries were the vessels most commonly containing thrombi, but arterioles and small arteries were quite frequently affected. Angiomatous appearances were common in the region of involved vessels (Fig. 1), being probably due to opening up of collaterals. Cellular reaction in or about the vessel wall was absent, or at the most amounted to a slight and scattered response best seen in interstitial septa in the myocardium. Often the thrombus was continuous with and replaced a segment of (necrosed) vessel wall (Fig. 2). Lesions of the vessel wall in the absence of intraluminal thrombi are said to occur but in these cases were hard to find.

Characteristic thrombi were very numerous throughout the myocardium and in the adrenals, especially in the subcapsular zone. In both pituitaries thrombi were present, more frequently in the posterior lobe; in case 1 there was a small infarct of the anterior lobe. No glomerular lesion was seen in the kidney but thrombi were present in the vasa recta. In the spleen scanty thrombi were seen in occasional vessels in fibrous septa, but not in the pulp. Thrombi were present in vessels in the exocrine and endocrine glands of the pancreas. In the liver arterioles in the portal triada and one central vein contained thrombi. Vessels in all coats of the stomach and small intestine contained thrombi, including a vessel in the base of a chronic peptic ulcer in case 2. In the brain vessels were affected in the cortex, white matter, basal ganglia, and cerebellar cortex. The diaphragm of case 1 and the pectoral muscle of case 2 contained thrombi, though these were sparse in the latter. Several blocks of skin showing petechial haemorrhage did not contain vessels with thrombus. No thrombus was present in the hyperplastic marrow in which megakaryocytes were numerous. No lesion was seen in the endometrium of case 2.

\section{DISCUSSION}

Moschcowitz (1925) in describing his original case attributed the hyaline masses in terminal arterioles and capillaries to agglutinated red cells, since a platelet count had not been performed and purpura had not been a marked feature in his case. However, it is of interest that he recorded also the red cell osmotic fragility as increased, since haemolysis started at $0.8 \% \mathrm{Na} \mathrm{Cl}$. He concluded that death 'resulted from some powerful poison, which had both agglutinative and haemolytic properties'.

Until recently most investigators have followed Baehr, Klemperer, and Schifrin (1936) in attributing the hyaline masses to agglutinated platelets so that the term 'thrombotic thrombocytopenia' proposed by Singer, Bornstein, and Wile (1947) seemed a reasonable one. However, more refined techniques have thrown considerable doubt on the theory that these masses are platelet in origin. Stuart and Macgregor-Robertson (1956), using a battery of histochemical stains, felt that they were fibrinous in nature and this has been confirmed by Craig and Gitlin(1957), using an immuno-fluorescent technique. Moreover, in more recent years there has been general agreement that the blockage of small vessels is secondary to vascular damage rather than primary to it. Relatively little attention has yet been paid to the haemolytic anaemia which is the other essential 


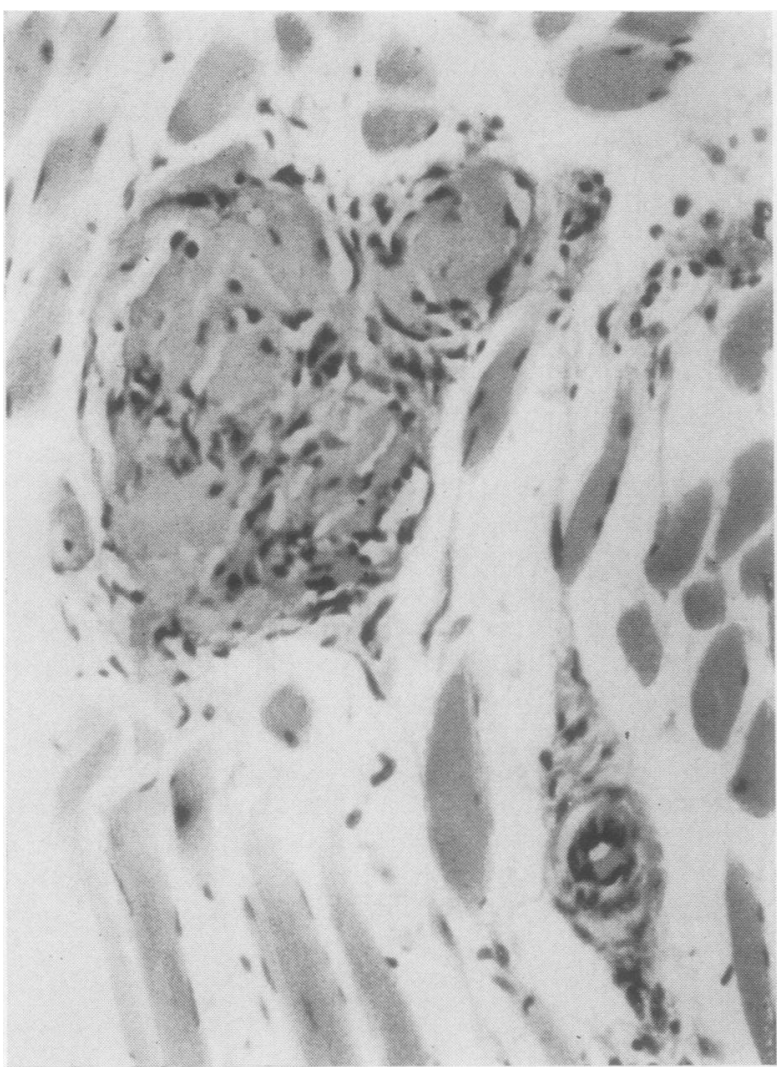

FIG. 1. Myocardium in case $2 \times 100$ (stained by haemotoxylin and eosin). There are numerous small blood vessels, some of which contain thrombus.

feature of the condition. This is invariably present, whereas other features may be absent (Symmers, 1956).

Any theory as to the pathogenesis of the condition must explain the red cell changes, which in our two cases were certainly impressive. In the Leishmanstained film of both of them there was much anisocytosis and poikilocytosis of red cells, the latter feature being particularly marked with bizarre shaped fragments, some resembling schistocytes, others 'helmet cells'. In addition about $30 \%$ of the red cells had the appearance of spherocytes (Fig. 4), the presence of which was confirmed by the saline osmotic fragility which was markedly increased in both cases.

Search of the literature shows that only in seven cases of the condition in adults has an increase of the red cell fragility or spherocytosis been noted. Muirhead, Crass, and Hill (1948) stated that the fragility was normal on the second day of admission in their case but a marked increase together with spherocytosis

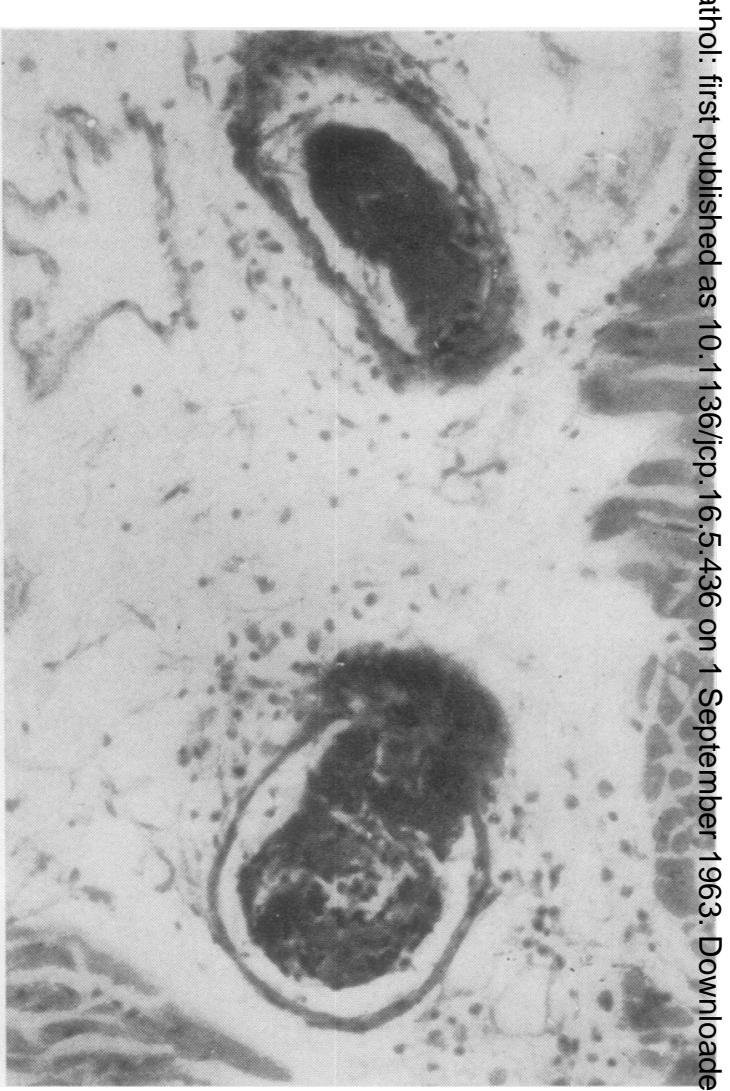

FIG. 2. Myocardium of case 2 (stained by P.A.S.) $\times 10 \varrho^{2}$ Two small vessels are shown containing thrombus, whic has replaced the vessel wall at one point.

was found on the eighth day. Singer, Motulsky, and Shanberge (1950) made the only detailed study of red cell fragility in their case and again found it 3 normal on admission, but on two subsequent occasions demonstrated a marked increase. In addition they found an increase in mechanical fragility, but a normal lysolecithin and heat fragility. These findings they considered to be the pattern of an acquired idiopathic haemolytic anaemia, possibly of non $\gamma$ globulin type since the Coombs test was negative. In o children changes in the red cells have been found $N$ more frequently. MacWhinney, Packer, Miller, and Greendyke (1962), in a recent review of the $19 \mathrm{\omega}$ recorded cases of thrombotic thrombocytopenia in childhood, state that in all the 11 cases where the peripheral blood smear was examined, abnormalities of red cell morphology were noted.

Apart from the morphological changes in the red cells there seems unanimity in the other haematological findings. There is a marked increase of reticulocytes, often with occasional normoblasts. The 


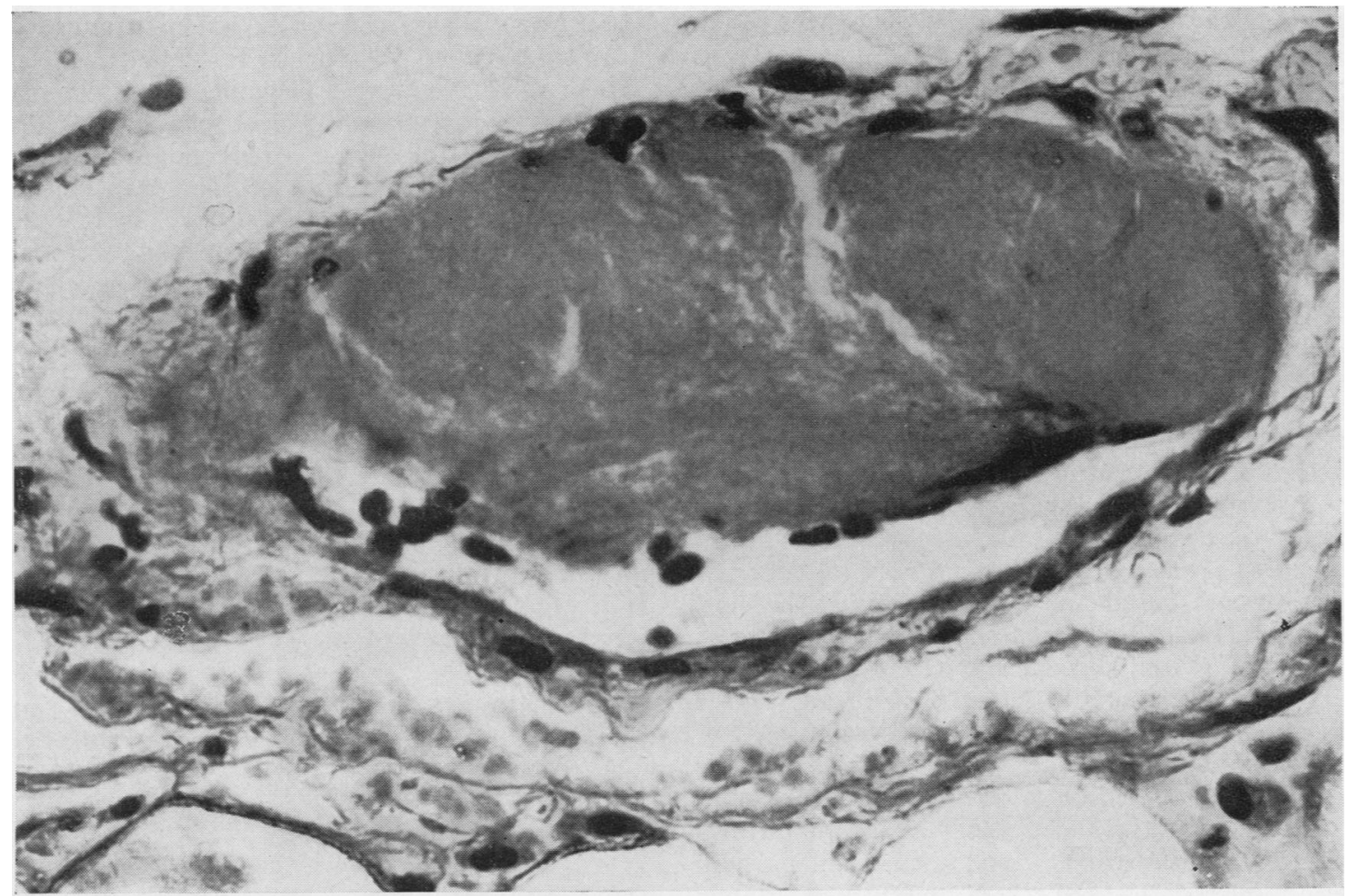

FIG. 3. Small epicardial vessel of case 2 showing thrombus replacing the vessel wall. Haematoxylin and eosin $\times 900$.

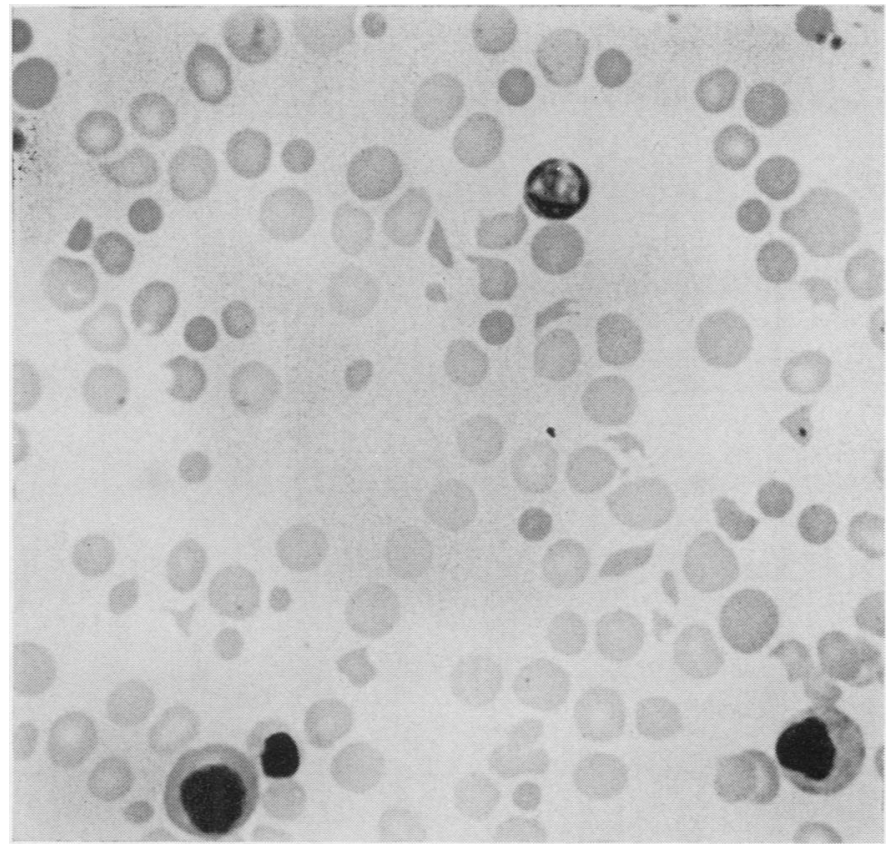

FIG. 4. Blood film of case $1 \times 950$. 
white cell count may be increased, sometimes with a leukaemoid picture, due to a neutrophil leucocytosis with a shift towards immaturity. Thrombocytopenia is marked but platelets have only rarely been recorded as completely absent; moreover, and certainly in our two cases in contrast to most other types of thrombocytopenia, platelet morphology does not seem to be greatly disturbed. The bone marrow smears usually show simply a reactive hyperplasia in the red cell series, with a normal or slightly increased number of megakaryocytes, though some have found qualitative changes in the latter such as vacuolation or hyalinization of the cytoplasm. Finally there is a moderate rise in the serum bilirubin together with increased excretion of pigment in the urine and faeces.

In the past there has been doubt as to the mechanism of the thrombocytopenia since it could be due to impaired production, or to rapid removal either by deposition in peripheral vessels or by lysis. The short survival time of transfused platelets and red cells as shown by Hirsch and Gardner (1952) and Adelson et al. (1954) favours the latter. Nevertheless, efforts to demonstrate antibodies either against platelets or red cells have so far failed. In this connexion the experiments of Bedson (1922) in which he demonstrated that anti-platelet serum in the rabbit also caused damage to capillary endothelium and purpura are of interest. The red cell changes would certainly be in keeping with the view of Dameshek (1955) that thrombohaemolytic thrombocytopenic purpura lis a triple auto-immune disorder affecting red cells, platelets, and small blood vessels.

\section{ADDENDUM}

Since submitting this work Brain, Dacie, and Hourihane (1962) have described similar red cell changes in six adult cases of thrombotic thrombocytopenic purpura, in a series of 25 cases of micrangiopathic haemolytic anaemia, in all of which there was severe involvement of renal arterioles and capillaries.
They stress the similarity of the red cell changes in thrombotic thrombocytopenia to those found in certain cases of uraemia, disseminated carcinoma, malignant hypertension, microscopic polyarteritis, and in a recent case where a regurgitant stream of red cells was in contact with a Teflon graft bare of endothelium following cardiac surgery. In this last patient the red cell changes and haemolytic anaemia is disappeared following further surgery to cover the $\overrightarrow{0}$ graft. They postulate that the red cell changes in all these conditions are due to mechanical injury to red cells in small blood vessels with damaged endothelium, particularly in the kidney. However, the kidneys were strikingly normal in both our cases and $\vec{\sigma}$ we are not convinced that passage of red cells $r$ through damaged vessels, which in thrombotic thrombocytopenic purpura seem to become rapidly blocked by hyaline material free from red cells, can be a complete explanation for the striking changes in red cell morphology.

We wish to thank Dr. G. P. Baker, under whose care both these patients were admitted, for agreeing to publication of the case reports.

\section{REFERENCES}

Adelson, E., Heitzman, E. J., and Fennessey, J. F. (1954) Arch. intern. Med., 94, 42.

Bachr, G., Klemperer, P., and Schifrin, A. (1936). Trans. Ass. Amer. Phycns, 51, 43.

Bedson, S. P. (1922). J. Path. Bact., 25, 94.

Brain, M. C., Dacie, J. V., and Hourihane, D. O'B. (1962). Brit. J. Haemat., 8, 358.

Craig, J. M., and Gitlin, D. (1957). Amer. J. Path., 33, 251.

Dameshek, W. (1955). Amer. J. Med., 18, 315.

Hirsch, E. O., and Gardner, F. H. (1952). J. Lab. clin. Med., 39, 556. MacWhinney, J. B., Packer, J. T., Miller, G., and Greendyke, R. M. (1962). Blood, 19, 181.

Moschcowitz, E. (1925). Arch. intern. Med., 36, 89.

Muirhead, E. E., Crass, G., and Hill, J. M. (1948). Amer. J. clin. Path., $18,523$.

Singer, K., Bornstein, F. P., and Wile, S. A. (1947). Blood, 2, 542.

Singer, K., Motulsky, A. G., and Shanberge, J. N. (1950). Blood, 5, 434.

Stuart, A. E., and Macgregor-Robertson, G. (1956). Lancet, 1, 475. Symmers, W. St. C. (1956). Ibid., 1, 592. 